\title{
What Factors Affect Stocks' Abnormal Return during the COVID-19 Pandemic: Data from the Indonesia Stock Exchange
}

\author{
Yohanes Indrayono
}

\section{ABSTRACT}

This study identifies Indonesian investors' reactions to the drop in stock prices on the Indonesia Stock Exchange market, during the early months of the COVID-19 crisis, before and after the World Health Organization (WHO) announced that its global spread constitutes a pandemic. It also explores variables that influence stock returns on this market during the financial crisis caused by the COVID-19 pandemic. This study uses a regression analysis of $\mathbf{7 0}$ firms, listed on the Indonesia Stock Exchange to examine the pandemic's influence on trading volume, market capitalization, profitability, and book value for the period December 31, 2019, to April 30, 2020. The results show that stock returns were lower in the early period of the financial crisis caused by the pandemic. Firms' trading volumes, profitability and book values positively affected stock returns and their market capitalization negatively affected stock returns during the study period. This study contributes useful insights to the finance literature and stock-market participants in terms of dealing with stock markets during financial crises. This study recommends that in any crisis investors should begin buying stocks or increasing their stock purchases to achieve abnormal returns by choosing stocks that perform well in terms of firm profitability and book value by looking a number of financial factors.

Keywords: Book Value, Financial Crisis, Market Capitalization, Profitability, Stock Returns, Transaction Volume.

\section{INTRODUCTION}

Since the Great Depression of the 1930s, national and global economic and financial crises have usually been the consequences of policy failures and imbalances in economic systems. However, the present economic turmoil, around the world, is secondary to the global health crisis caused by the COVID-19 pandemic. Before any efforts can be made to control the present economic uncertainty, boosting the global economy heavily relies on controlling the transmission of this disease and tempering the pandemicbased financial panic. In addition to China, high numbers of COVID-19 cases have been reported worldwide, particularly in the US, Italy, and Spain. To minimize the transmission of this oftentimes lethal virus, every country around the world has enforced lockdowns and social distancing and this has impeded community and international economic activity. The resultants include serious disruptions to supply chains and consumer demand, and this has stunted national and global economic growth. Investors' withdrawal of funds by selling their shares from stock exchanges has been observed. This has caused stock market indices to drop dramatically, compared to the values of their closing prices on these same exchanges at the end of 2019. For instance, the Dow Jones Industrial Index (DJIA) decreased by $34.44 \%$, from December 31, 2019, to April 30, 2020; the Bombay Stock
Submitted : October 10, 2021

Published : November 04, 2021

ISSN: 2507-1076

DOI: $10.24018 /$ ejbmr.2021.6.6.1139

Yohanes Indrayono*

Faculty of Economics and Business, Universitas Pakuan, Bogor, West Java, Indonesia.

(e-mail: yindrayono@gmail.com)

(e-mail: yindrayono@unpak.ac.id)

*Corresponding Author
Exchange (BSE) dropped by 26.87\%; Japan's Nikkei was down by $30.03 \%$, and the Financial Times Stock Exchange (FTSE) decreased by $33.79 \%$.

Similar drops were also observed in other indices such as the Singapore' Straits Times Index (STI) down by $21.04 \%$, Australia's All Ordinaries (AORD) by $32.90 \%$, Brazil's Bovespa (BVSP) by $45.18 \%$, French Cac-40 Index (FCHI) by $34.09 \%$, the Deutsche Boerse AG German Stock Index (GDAX) by $34.02 \%$, Hongkong Hangseng Index (HIS) was down by $23.03 \%$ according to Yahoo Finance (May 2020). The Indonesia Stock Exchange (JKSE) suffered an even greater decline of $37.49 \%$ between the index's closing on December 31, 2019, and March 23, 2020, four days after the World Health Organization announced that the global spread of COVID-19 constituted a pandemic. Financial crises in stock markets are considered to occur when their indices decline by more than $20 \%$ in developing countries and by $35 \%$ in emerging markets (Patel and Sarkar, 1998); thus, Indonesia is presently in a financial crisis. The last time this phenomenon occurred was during the global financial crisis of 2008-2009, which originated on Wall Street and harmed investors, banks, and economies around the world (Indrayono, 2011; Guidolin and Tam, 2013).

The results of previous studies are inconsistent regarding the effects of some critical stock market variables (trading volume, market capitalization) and accounting variables 
(profitability and book value) on stock returns during periods of non-crisis. Previous studies also show that trading volume positively affects stock returns (Lee \& Rui, 2002; Ravichandran, \& Bose, 2012; Ur Rehman, \& Gul, 2017 ) and market capitalization negatively affects returns (Baur et al. 2012; Garcia, \& Liu, 1999; Meligkotsidou et al., 2019). However, Chen et al. (2012) and Pathirawasam (2011) argued that there is no correlation between stocks' trading volumes, market capitalization and stock market returns. Previous studies show that a stock's price-the-book value (PBV) has a significant effect on its returns (Majid and Benazir, 2015). However, there are controversial correlations between profitability, book value and stock returns (Aggarwal et al., 1992; AlNajjar, \& Riahi-Belkaoui, 1999; Hao, Jin, \& Zhang, 2011; Lei, \& Shcherbakova, 2015; Macagnan, 2009).

This study investigates how investors in the Indonesia stock market reacted to the present financial crisis when Indonesia's stock market index declined over the period January 1 to March 23, 2020, but experienced a technical rebound from March 24 to April 30, 2020. It also evaluates the influence of five variables (e.g., trading volumes, profitability, book values, stock returns and market capitalization) on Indonesia's stock market returns before and after March 23, 2020. To understand the drop in stock prices on the Indonesia Stock Exchange market in detail, stock market data of 70 firms listed on the Indonesia Stock Exchange uses and examines the pandemic's influence on trading volume, market capitalization, profitability, and book value for the period between December 31, 2019 and April 30, 2020. The study outcomes will be a useful insight to the stock-market related finance literature in terms of sudden financial crises. Finally, this study provides several recommendations with factual guidelines for any crisis on how investors should begin buying stocks by choosing stocks that perform well in terms of firm profitability and book value looking at several underlying financial factors.

The remainder of this study is organized into four sections. Section 2 reviews previous studies that are relevant to the reported financial crisis with stock markets, stock returns and abnormal returns. Orientation to past studies related to trading volume, market capitalization, profitability, and book value to stock returns are also underpinned. Section 3 and explain the study methodology (conceptual model) and data process to get the targeted aims. The results and discussion are addressed in Section 5. Finally, discussion and concluding remarks are presented in 6 and 7, respectively.

\section{LITERATURE REVIEW}

\section{A. COVID-19 Pandemic and Financial Crisis}

The coronavirus, or COVID-19, first infected humans in Wuhan, Hubei Province, China, where it spread and infected thousands in that city from the end of December 2019, to the beginning of January 2020. To prevent the virus from spreading, the government of China locked down Wuhan city, which meant people were prohibited from entering and leaving. Nevertheless, the virus still infected people from countries outside China and international travel spread it to the rest of the world. The spread of COVID-19 was massive as it infected large populations in many countries, so much so that on March 11, 2020, the World Health Organization announced that COVID-19 is a pandemic. According to worldometer.info, 214 countries the world over have reported COVID-19 cases, with more than five million cases and 320 thousand deaths as of May 31, 2020 (Wordometers, May 2020).

To control the spread of the coronavirus, during the pandemic, national, state/provincial, civic and regional borders have been locked down and social distancing has been introduced, all of which has either slowed or stopped economic activity. Restricting social and economic activities within communities is causing serious disruptions to market demand and supply and has reduced economic output in every country. This has caused investors to sell their shares on stock exchanges in preferences for holding cash; consequently, stock market indices around the world have dramatically dropped from their closing prices of the end of 2019.

The highest number of COVID-19 cases, in addition to those in China, occurred in the middle of February 2020 (wordometer.info). The China SSE Composite Index (000001.SS) fell by $12.79 \%$ on March 23, 2020, together with other countries' indices. This was mainly triggered by the decline in the Dow Jones Industrial Average (DJIA), which had repercussions on stock indices, the world over, that same day. The Indonesia Stock Exchange (JKSE) was also down by $37.49 \%$ as of March 23, 2020, compared to the closing index on December 31, 2019.

No previous infectious disease outbreak, including the Spanish Flu, has affected the stock market as forcefully as the COVID-19 pandemic. Previous pandemics left only mild traces on the US stock market (Baker et al., 2020). Recently, Phan, \& Narayan (2020) studied the country responses and the reaction of the stock market to COVID-19 by a preliminary exposition. Mazur et al. (2020) worked on the COVID-19 and 2020 stock market crash. This study showed the US stock market performance during the crash of March 2020 triggered by COVID-19. Al-Awadhi et al. (2020) investigated the death and contagious infectious diseases based on the impact of COVID-19 virus on stock market returns. This study investigates whether contagious infectious diseases affect stock market outcomes by using panel data regression analysis. Ashraf (2020) studied the scope of the economic impact of government interventions during the COVID-19 pandemic from the viewpoint of the financial markets. Wagner (2020) analysed the scope of the post-COVID-19 world with stock market behaviour. Thus, it is evident that several research works have been carried out since COVID-19 pandemic started and the scopes were diverse. With the recent stock market recession all over the world and based on the unexpected pandemic crisis, this study provides a unique view of the expected future the economy and of a company following the case in the Indonesia Stock Exchange.

Financial crises in stock markets occur when stock market indices decline by more than $20 \%$ in developing countries and 35\% in emerging economies (Patel and Sarkar, 1998), a phenomenon that last occurred in 2008 (Indrayono, 2011; Guidolin and Tam, 2013). The period January 1 to April 30, 
2020 - when the COVID-19 outbreak occurred - is considered the period during which the present financial crisis began; this is because stock market declines in both developing and emerging markets met the above criteria during these four short months (Patel and Sarkar, 1998).

Fig. 1 shows graphs of the major stock indices of US, the UK, Germany, France, Russia, Japan, Hongkong, China, Singapore, Australia, India, South Korea, Brazil, and Mexico for the period January 1 to mid-May 2020, during which the COVID-19 pandemic was still occurring all over the world. It can be seen that country indices dropped to their lowest levels on March 23, 2020. The DJIA was down by $34.44 \%$; the Russell 2000 by $39.64 \%$; the FTSE 100 by $33.79 \%$; the DAX by $34.02 \%$; the FCHI by $34.52 \%$; the MOEX by $30.64 \%$; the Nikkei 225 by $30.03 \%$; the Hangseng by $23.03 \%$; the STI by $21.04 \%$; AORD by $32.90 \%$; the BSE Sensex by $26.87 \%$; the KOSPI by 31.86 ; the BOVESPA by $45.18 \%$; and IPC Mexico by $25.81 \%$.

Fig. 2 shows a trend line of the Indonesia Stock Exchange for the period January 1, 2020 to mid-May 2020, the height of the COVID-19 pandemic. It can be seen that the Indonesian stock exchange index dropped to its the lowest level on March 23, 2020.

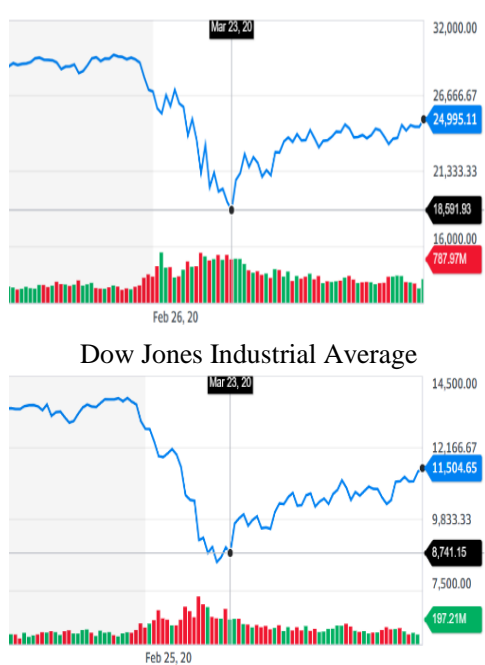

DAX PERFORMANCE-INDEX

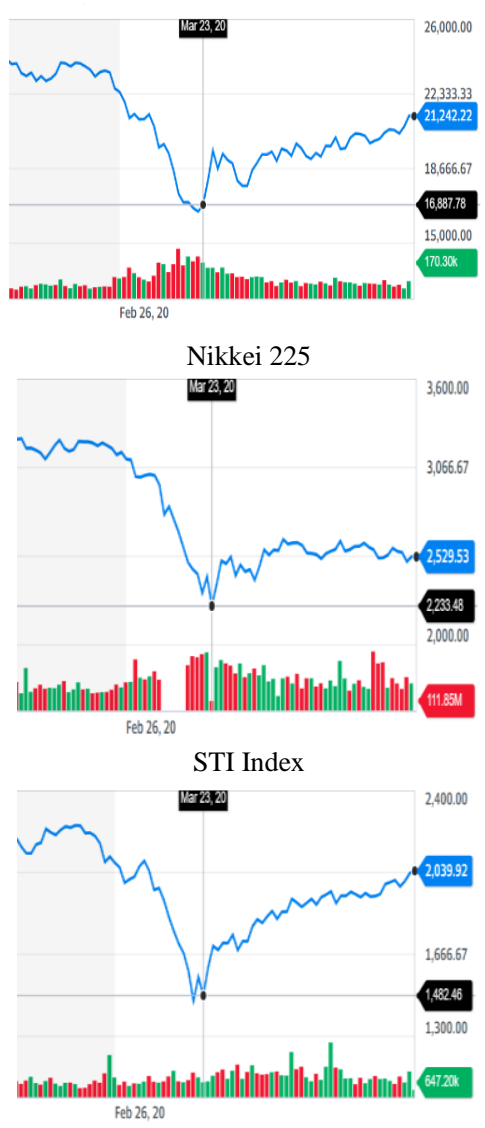

KOSPI Composite Index

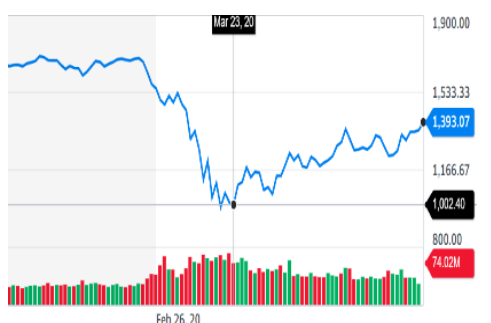

Russell 2000

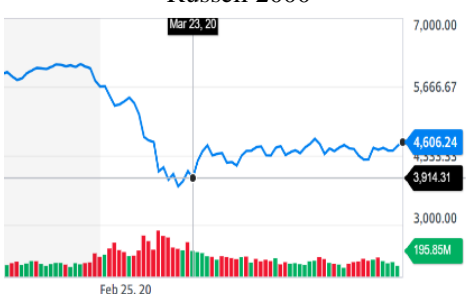

FCHI CAC 40

[Mar23,2]

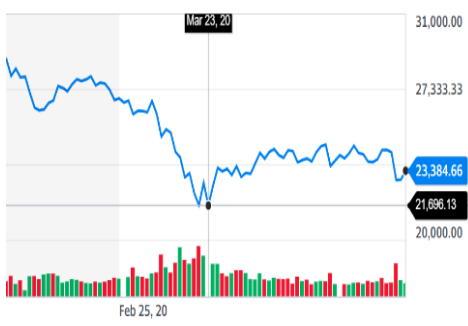

HANG SENG INDEX
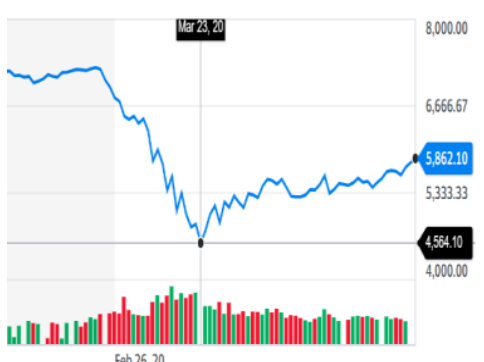

ALL ORDINARIES

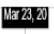

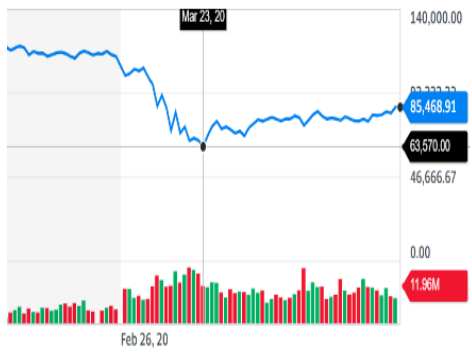

IBOVESPA

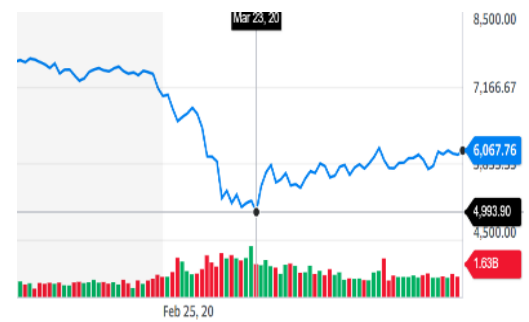

FTSE 100

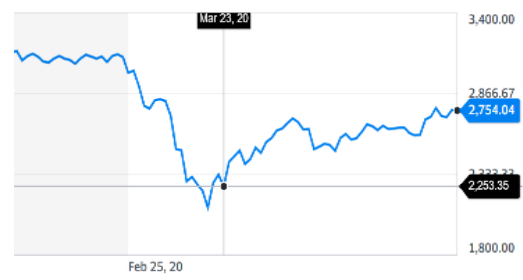

MOEX Russia Index

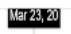

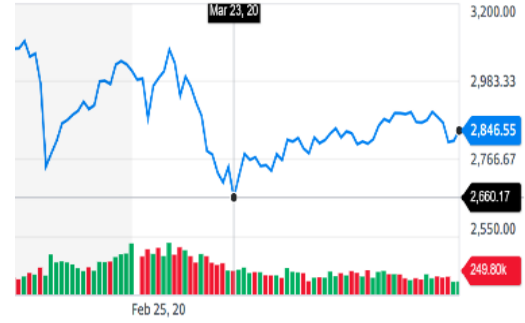

SSE Composite Index

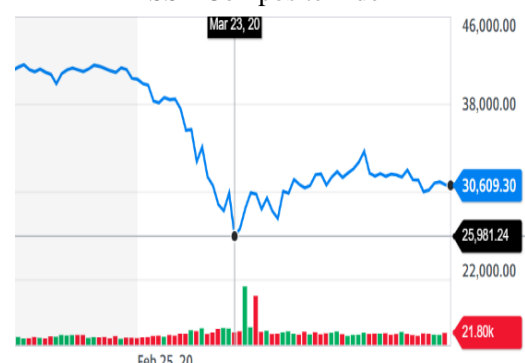

S\&P BSE SENSEX

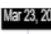

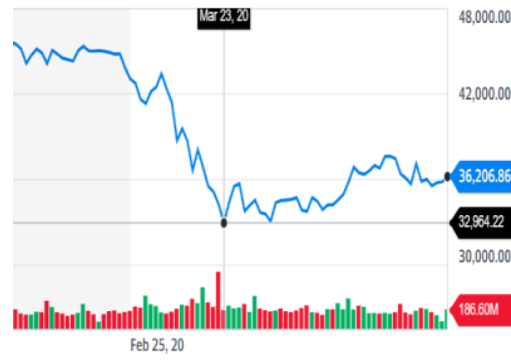

IPC MEXICO

Fig. 1. Countries Stock Index During The Financial Crisis Source: Yahoo Finance (May, 2020). 


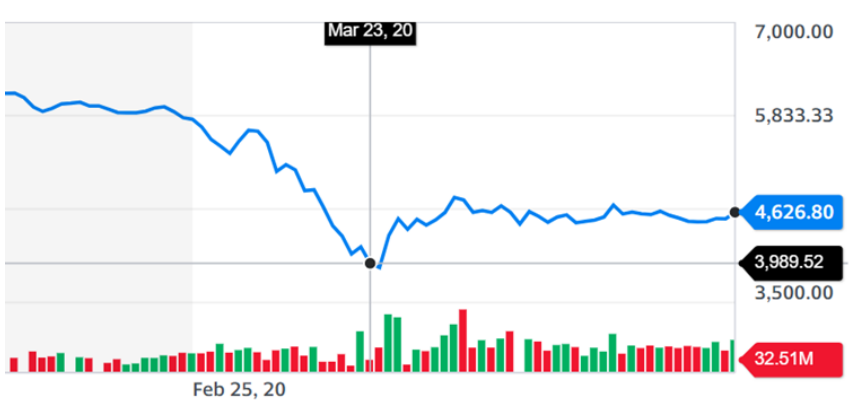

Fig. 2. Indonesian Stock Exchange Index During The Financial Crisis. Source: Yahoo Finance (May, 2020).

\section{B. Global Financial Crisis and the Impact on Investment}

The rapid global spread of the coronavirus created an unprecedented level of risk on financial markets, worldwide. Ali et al. (2020) explored the pandemic's direct impact on investors in terms of equity, debt, and the value of shares in bitcoin, gold, and oil. Within a hundred days, approximately $30 \%$ of wealth was erased from bourses around the globe. The consequence has been increasing panic and market deterioration as the coronavirus moved from epidemic to pandemic proportions. The situation worsened as the global spread exceeded geographical and continental boundaries. Returns on relatively safe commodities, like gold (although least volatile) turned negative as the coronavirus spread throughout the US.

Stock market returns respond to disasters, sports events, tragic news, environmental changes, pandemic diseases, and political events. With this in mind, Al-Awadhi et al. (2020) used panel data regression testing to empirically conclude that stock returns are negatively related to both the daily growth in the total number of new confirmed coronavirus cases and deaths by country and day. However, the financial literature enumerates several factors that affect stock returns.

This study investigates whether contagious infectious diseases affect stock market outcomes. As a natural experiment, we use panel data analysis to test the effect of the COVID-19 virus, which is a contagious infectious disease, on the Chinese stock market. The findings indicate that both the daily growth in total confirmed cases and in total cases of death caused by COVID-19 have significant negative effects on stock returns across all companies.

Research in experimental psychology suggests that, most people tend to "overreact" to unexpected and dramatic news events, which is in violation of Bayes' rule. Bayes' theorem is an elementary proposition ofvprobability theory. It provides a way of updating, in light of new information, one's probability that a proposition is true. There is also evidence that unexpected stock market returns are negatively related to unexpected changes in the volatility of stock returns. This negative correlation provides indirect evidence of a positive correlation between expected increased risk and market volatility (French et al., 1987).

\section{Variables Influencing Stock Market Returns}

According to Amihud (2020), stock market returns can be passively influenced by contemporaneous unexpected illiquidity that more strongly affects small firms' stocks and causes variations in their returns over time. In an extreme case of an increase in illiquidity, as had occurred during the October 1987 crash, there were substitutions of less-liquid to more-liquid stocks in a "flight to liquidity," where moreliquid stocks declined less in value, compared to less-liquid stocks, after controlling for market effects and these stocks' beta coefficients. A beta describes the capital asset pricing model that describes the relationship between systematic risk and expected return for assets (usually stocks).

Fama and French (2008) explored the pervasiveness of net stock issues, accruals, momentum, profitability, and asset growth that are associated with anomalous average returns via sorts and cross-section regressions for both large and small stocks. They found that net stock issues, accruals, book-to-market ratios, and profitability result in similar average regression slopes across size groups. They concluded that all anomalies could be rough proxies for expected cash flows and they defined differences in expected returns as being either due to irrational pricing or to rational risks. Accordingly, variables that predict future cash flows and returns are not indicative of whether variations in expected returns are caused by risk or mispricing. Similarly, Sadaka (2007) found that expected returns are negatively correlated with expected earnings growth. Since dividend yields predict both profitability and returns, the expectations of returns may cause variations in dividend yields and expected profitability.

Shocks to profitability are positively correlated with stock returns. Firms that incur positive profitability shocks tend to experience immediate stock price increases, whereas firms that incur negative profitability shocks tend to experience immediate stock price decreases. In addition, less financially distressed firms are more profitable, meaning they have higher than expected profitability and, all else being equal, should earn higher expected returns than firms that are more financially distressed. Therefore, the distress effect is consistent with the positive profitability-expected-return relation. Finally, sorting on earnings surprises should produce an expected profitability spread between extreme portfolios of stocks of large- and small-capitalized firms. Moreover, the size, book-to-market, momentum, and liquidity effects cannot account for either the low average returns earned by stocks with high exposure to systematic volatility risk or stocks with high idiosyncratic volatility.

Baker and Wurgler (2006) found that when beginning-ofperiod proxies for sentiment are low, subsequent returns are relatively high for stocks that are young, highly volatile, unprofitable, non-dividend-paying, show extreme growth, or are distressed. When sentiment is high, however, these categories of stocks earn relatively low returns. Moreover, economic activity, financial leverage, and stock trading affect excessive returns.

Capital inflows, which rely on foreign direct investment (FDI) and workers' remittances, affect stock market performance, especially in developing countries and emerging markets. Claessens et al. (2002) demonstrated a positive relation between market capitalization and FDI. In contrast, Naik and Padhi (2015) concluded that stock market development contributes to economic growth in all of the proxies for financial-development indicators such as investment ratio, trade openness and exchange rates. Moreover, trade value and turnover ratios positively and robustly influence economic growth. Nevertheless, market capitalization may not be the correct channel for 
accelerating economic growth in emerging economies. This finding contradicts the findings reported in the mainstream literature. Therefore, the effect of market capitalization on enhancing economic growth in developing countries remains controversial. It is also this paper's contribution to the extant literature.

Along a different vein, studies of the dynamics between trading volume and volatility postulate that differences in investor opinions and expectations are the source of changes in these factors, or that introducing information to markets determines the trading volume and volatility. Both approaches are used to predict the role of trading volume and conditional volatility in boosting investment and economic growth (Poon, \& Granger, 2003). Overreactions to noise trading and earnings announcements, stock market liberalization, foreign trading and the volatility of cash flows to equity markets, bonds-yield volatility, and radical differences in exchange rates can all cause, or partly cause, a stock market crisis. By analysing changes in emerging markets, Sabri (2008) found that stock-trading values and monthly trading volatilities increase in many stock markets. $\mathrm{He}$ also reported that the volume in terms of stock price movements is integral to all of the studied markets. The correlation between the two variables of trading volume and stock price volatility increases over time.

Sabris' (2008) research covers a sample of 8 of the 15 Arab stock markets included in the Arab Monetary Fund database, using monthly data from 1994 to 2006. The study found that there is an increase in both trading volume and stock price volatility, which may be considered a recent phenomenon in the majority of the Arab stock markets. The study also found that the volume-stock price movements are significantly integrated for all of the selected markets, while the highest (to lowest) correlation coefficients between volume and stock price movements were found in the stock markets of Saudi Arabia, Amman, Muscat, and Kuwait (in that order). Finally, he found that the correlation between volume and price movement is higher in the stock markets of the Arab oil states compared to Arab nonoil states.

Girard and Biswas (2007) concluded that emerging markets show much stronger positive relations between the unpredictable flow of information to a market and market volatility (in unexpected volume). They also found a negative relation between the expected volume and market volatility, which may indicate that informed traders are inclined to lead the speculative trading activity and drive bid-ask spreads higher.

By analysing the performance of nine major stock markets, with reference to their stock returns, trading volume, and volatility patterns, Rui et al. (2001) found that persistence in volatility is evident even after incorporating the contemporaneous and lagged volume effects that are proxies for information flow. Therefore, studying the joint dynamics of stock prices and trading volumes is more beneficial than focusing only on the univariate dynamics of stock prices.

Investors' behaviors cause financial variables and market anomalies to affect emerging markets more than they do stable ones. Therefore, this study uses regression analysis to study the reactions of Indonesian investors in the stock market during the COVID-19 crisis and its relation to the drop in stock prices. As such, it explores the influence of the stock trading volume, market capitalization, firms' profitability, and firms' book value on stock returns during the COVID-19 pandemic. Therefore, the following hypotheses of this study are explored as follows:

H1 - Financial crisis negatively affects stocks' returns;

H2 - Stocks' trading volumes positively affect these stocks' returns;

H3 - Stock's market capitalizations negatively affect these stocks' returns;

H4 - Firms' profitability positively affects their stocks' returns;

H5 - Firms' book values positively affect their stocks'returns;

H6 - Stocks' trading volumes positively affect these stocks' abnormal returns;

H7 - Stocks' market capitalizations negatively affect these stocks' abnormal returns;

H8 - Firms' profitability positively affects their stocks' abnormal returns;

H9 - Firms' book value positively affects their stocks' abnormal returns.

\section{RESEARCH METHOD}

This study investigates the factors that affected stock returns on the Indonesian stock market before and after March 23, 2020, the date the financial crisis related to the COVID-19 pandemic hit a trough. To test whether any of these firms' stocks experienced abnormal returns during the period, we use the independent t-test. An abnormal return $(\mathrm{AR})$ is a stock return that is above the market return: (AR) $=\mathrm{SR}-\mathrm{MR}>0$; stock return $(\mathrm{SR})=(\mathrm{Pt}-\mathrm{Pt}-1) / \mathrm{Pt}-1$; and market return $(\mathrm{MR})=(\mathrm{Mt}-\mathrm{Mt}-1) / \mathrm{Mt}-1$.

To assess the effect of stocks' trading volumes and market capitalizations on these stocks' returns and abnormal returns, we use regression analyses using the formula:

$$
\begin{aligned}
& \mathrm{SR}=\alpha+\beta 1 \mathrm{Vol}+\beta 2 \mathrm{MCap}+e \\
& \mathrm{AR}=\alpha+\beta 1 \mathrm{Vol}+\beta 2 \mathrm{MCap}+e
\end{aligned}
$$

Trading volume ( $\mathrm{Vol})$ is the daily stock-trading volume, which is the sum of the stocks traded during the period under review. Market capitalization (MCap) is the sum of the stocks outstanding times the stocks' closing prices, where MCap $=\sum$ (number of stocks outstanding x stocks' market prices).

To review the effect of stock profitability and book value on stocks' returns and abnormal returns, we use regression analyses using the following formulas:

$$
\begin{gathered}
\mathrm{SR}=\alpha+\beta \text { 1 Vol }+\beta 2 \mathrm{MCap}+\beta 3 \mathrm{EPS}+\beta 4 \mathrm{BVS}+\beta \\
5 \mathrm{PER}+\beta 6 \mathrm{PBV}+e \\
\mathrm{AR}=\alpha+\beta 1 \mathrm{Vol}+\beta 2 \mathrm{MCap}+\beta 3 \mathrm{EPS}+\beta 4 \mathrm{BVS}+\beta \\
5 \mathrm{PER}+\beta 6 \mathrm{PBV}+e,
\end{gathered}
$$

where,

$\alpha$ and $\beta$ are standard regression paraments, $e$ is error terms. 
$\mathrm{SR}$ is the stock returns determined by $(\mathrm{Pt}-\mathrm{Pt}-1) / \mathrm{Pt}-1(\mathrm{Pt}$ is the stock price on day $\mathrm{t}$; Pt-1 is the stock price on day $\mathrm{t}-1)$.

$\mathrm{AR}$ is the abnormal returns determined by $(\mathrm{Pt}-\mathrm{Pt}-1) / \mathrm{Pt}-$ 1 ; and market return $(\mathrm{MR})=(\mathrm{Mt}-\mathrm{Mt}-1) / \mathrm{Mt}-1(\mathrm{Mt}$ is stock index on day $\mathrm{t}$; Mt-1 is stock index on day $\mathrm{t}-1)$.

EPS is the earnings per share determined by the net profit after tax/ $/$ stocks outstanding.

PER is the price-to-earnings ratio determined by the stock price/EPS.

BVS is the book value per share, determined by (total assets - total liabilities) $/ \sum$ stocks outstanding.

$\mathrm{PBV}$ is the price-to-book value, determined by the stock price/BVS.

This study uses data on the stocks of 70 listed firms with the largest market capitalizations on the Indonesia Stock Exchange; this represents more than $75 \%$ of the total market capitalization of this index. All of these firms' stocks experienced a high daily average of trading volumes during the period January 1 to April 30, 2020. A detail firms' financial information from the Indonesia Stock Exchange firms' 2019 annual reports has been obtained. To overcome the statistical bias and related regression issues, this study cautiously examines the following concerns.

\section{RESULTS AND FINDINGS}

A. Stock Returns before and after the WHO's COVID-19Pandemic Announcement on March 11, 2020

According to our first assumption stock returns are higher during periods after financial crises than before financial crises. We analyse, from the sample, whether there were differences in stocks' returns and stocks' abnormal returns before and after March 11, 2020, the date the WHO announced that the spread of COVID-19 is now a pandemic. That is, even though the financial crisis related to the COVID-19 pandemic is not over, we can still extrapolate the findings to a post-financial-crisis period.

\begin{tabular}{cccccc}
\multicolumn{6}{c}{ TABLE I A: MEAN OF STOCK RETURN AND STOCK ABNORMAL RETURN } \\
\hline Variable & Period & $\mathrm{N}$ & Mean & $\begin{array}{c}\text { Std. } \\
\text { Deviation }\end{array}$ & $\begin{array}{c}\text { Std. Error } \\
\text { Mean }\end{array}$ \\
\hline Stock return & Before & 4060 & -1.0304 & 3.48460 & .05469 \\
& After & 1820 & 1.0334 & 5.44801 & .12770 \\
\hline $\begin{array}{c}\text { Stock } \\
\text { abnormal } \\
\text { return }\end{array}$ & Before & 1787 & 1.8271 & 2.18047 & .05158 \\
\hline
\end{tabular}

Table I A shows the mean stock return and mean abnormal return before and after the March 11, 2020, announcement. The average stock return after the pandemic announcement was higher than before the announcement, with a mean equal to 1.0334 , compared to -1.0304 . The average of stocks' abnormal returns after the pandemic announcement was higher than before the announcement, with a mean of 3.5203 , compared to -1.8271 .

Table I B shows the independent samples test of stocks' returns and abnormal returns before and after the pandemic announcement. Stock returns after the pandemic announcement were higher than they were during the period before the pandemic announcement, with a 95\% confident level $(\alpha=5 \%$ ( $\mathrm{t}$ after $=-14.856$ is higher than $\mathrm{t}$ before $=$ 17.454), a significance of.000 (<.05) and a Levene's test
$\mathrm{F}=351.604$ at sig..000 (<.05). These stocks' average abnormal returns after the pandemic announcement were also higher than during the prior period $(\mathrm{t}$ after $=-12.381$ was higher than $\mathrm{t}$ before $=-14.686$ ) with a significance of.000 $(<.05)$ and a Levene's test $\mathrm{F}=238.045$ at sig..000 $(<.05)$.

TABLE I B: INDEPENDENT SAMPLES TEST OF STOCK RETURN AND STOCK

\begin{tabular}{|c|c|c|c|c|c|c|}
\hline \multirow[b]{2}{*}{ Variable } & & \multicolumn{2}{|c|}{$\begin{array}{c}\text { Levene's Test } \\
\text { for Equality of } \\
\text { Variances }\end{array}$} & \multirow[t]{2}{*}{$\mathrm{t}$} & \multirow{2}{*}{$\begin{array}{l}\text { Sig. } \\
(2- \\
\text { tailed })\end{array}$} & \multirow[t]{2}{*}{$\begin{array}{l}\text { Std. Error } \\
\text { Difference }\end{array}$} \\
\hline & & $\mathrm{F}$ & Sig. & & & \\
\hline \multirow{2}{*}{$\begin{array}{l}\text { Stock } \\
\text { return }\end{array}$} & $\begin{array}{c}\text { Equal } \\
\text { variances } \\
\text { assumed } \\
\end{array}$ & \multirow[b]{2}{*}{351.604} & \multirow[b]{2}{*}{0.000} & -17.454 & 0.000 & 0.11824 \\
\hline & $\begin{array}{c}\text { Equal } \\
\text { variances } \\
\text { not } \\
\text { assumed }\end{array}$ & & & -14.856 & 0.000 & 0.13892 \\
\hline \multirow{2}{*}{$\begin{array}{c}\text { Stock } \\
\text { abnormal } \\
\text { return }\end{array}$} & $\begin{array}{c}\text { Equal } \\
\text { variances } \\
\text { assumed } \\
\end{array}$ & \multirow[b]{2}{*}{238.045} & \multirow[b]{2}{*}{0.000} & -14.686 & 0.000 & 0.11529 \\
\hline & $\begin{array}{c}\text { Equal } \\
\text { variances } \\
\text { not } \\
\text { assumed }\end{array}$ & & & -12.381 & 0.000 & 0.13676 \\
\hline
\end{tabular}

\section{B. The Effect of Stock-trading Volume, Market} Capitalization, and Accounting Measures on Stock Returns

Table II shows the regression results for the relationship between trading volume (Vol), market capitalization (MCap), earnings per share (EPS), book value per share (BVS), the price-to-earnings ratio (PER), the price-to-book value (PBV) and stock returns (SR). The trading volume (Vol) positively affected stock returns (SR) for the period January 1 to April 30, 2020 ( $b=0.226$; $\mathrm{t}=3.513$, and sign. $=0.000<0.05$ ) and after the WHO's COVID-19-pandemic announcement $(b=0.884 ; \mathrm{t}=6.256$, and sign. $=0.000<0.05)$. But for the period before the announcement, the trading volume negatively affected stock returns (SR) with $b=-$ $0.294, \mathrm{t}=4.812$, and sign. $=0.000(<0.05)$. These results support that stocks' trading volumes positively affect stock returns, except for the period before the WHO announcement. Stock market capitalization (MCap) positively affected stock returns for the period before the announcement, with $\mathrm{b}=0.077 ; \mathrm{t}=2.418 ;$ and sign. $=0.016$ $(<0.05)$ and had no effect on the period between January 1 and April 30, 2020 and the period after the WHO announcement.

Earnings per share (EPS) positively affected stock returns during the period before the announcement, with $b=.001$; $\mathrm{t}=3.378$; and sign.=0.001 $(<0.05)$, but had no effect on stocks from January 1 to April 30, 2020, and after the WHO announcement. This result suggests that firms' profitability positively affects stock returns, but this is only for the period before the WHO announcement.

Book value per share (BVS) positively affected stock returns during the period before the WHO announcement, with $\mathrm{b}=0.0001 ; \mathrm{t}=3.838$; and sign. $=0.000(<0.05)$ had no effect from January 1 to April 30, 2020 and after the WHO announcement. This result supports that firms' book values positively affect their stock returns; again, this only applies to the period before the WHO announcement. The price- 
earnings ratio (PER) and the price-to-book value (PBV) had no effect on stock returns for the period January 1 to April 30, 2020, and after the WHO announcement that the spread

of COVID-19 constituted a pandemic.

TABLE II: The EFfect of Stock TRAding Volume, Market CAPITALization, AND AcCounting Variables to Stock Return

\begin{tabular}{|c|c|c|c|c|c|c|c|}
\hline $\begin{array}{l}\text { Dependent } \\
\text { Variables }\end{array}$ & & $\begin{array}{c}\text { Unstandardized } \\
\text { Coefficients } \\
\text { B }\end{array}$ & $\mathrm{t}$ & Sig. & $\mathrm{R}^{2}$ & $\mathrm{~F}$ & Sig. \\
\hline \multicolumn{8}{|c|}{ Period of Januari 2020 - April 2020} \\
\hline \multirow{9}{*}{ Stock Return } & (Constant) & -1.491 & -4.506 & 0.000 & \multirow{9}{*}{0.055} & \multirow{9}{*}{3.014} & \multirow{9}{*}{0.006} \\
\hline & Vol & 0.226 & 3.513 & 0.000 & & & \\
\hline & MCap & -0.015 & -0.430 & 0.667 & & & \\
\hline & EPS & 0.000 & 1.538 & 0.124 & & & \\
\hline & BVS & $-4.822 \mathrm{E}-5$ & -1.249 & 0.212 & & & \\
\hline & PER & $-8.667 \mathrm{E}-5$ & -0.193 & 0.847 & & & \\
\hline & PBV & 0.008 & 0.980 & 0.327 & & & \\
\hline & $\mathrm{N}$ & 5880 & & & & & \\
\hline & $\alpha$ & 0.05 & & & & & \\
\hline \multicolumn{8}{|c|}{ Period of Before The Announcement WHO Covid-19 Pandemic } \\
\hline \multirow{9}{*}{ Stock Return } & (Constant) & 0.461 & 1.483 & 0.138 & \multirow{9}{*}{0.104} & \multirow{9}{*}{7.096} & \multirow{9}{*}{0.000} \\
\hline & Vol & -0.294 & -4.812 & 0.000 & & & \\
\hline & MCap & 0.077 & 2.418 & 0.016 & & & \\
\hline & EPS & 0.001 & 3.378 & 0.001 & & & \\
\hline & BVS & 0.000 & -3.838 & 0.000 & & & \\
\hline & PER & 0.000 & 0.618 & 0.536 & & & \\
\hline & PBV & -0.006 & -0.714 & 0.475 & & & \\
\hline & $\mathrm{N}$ & 3920 & & & & & \\
\hline & $\alpha$ & 0.05 & & & & & \\
\hline \multicolumn{8}{|c|}{ Period of After The Announcement WHO Covid-19 Pandemic) } \\
\hline \multirow{9}{*}{ Stock Return } & (Constant) & -3.619 & -4.875 & 0.000 & \multirow{9}{*}{0.145} & \multirow{9}{*}{6.973} & \multirow{9}{*}{0.000} \\
\hline & Vol & 0.884 & 6.256 & 0.000 & & & \\
\hline & MCap & -0.134 & -1.750 & 0.080 & & & \\
\hline & EPS & 0.000 & -0.321 & 0.748 & & & \\
\hline & BVS & 7.763E-5 & 0.897 & 0.370 & & & \\
\hline & PER & -0.001 & -0.535 & 0.593 & & & \\
\hline & PBV & 0.021 & 1.118 & 0.264 & & & \\
\hline & $\mathrm{N}$ & 1960 & & & & & \\
\hline & $\alpha$ & 0.05 & & & & & \\
\hline
\end{tabular}

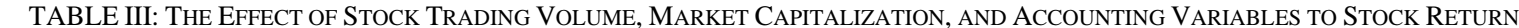

\begin{tabular}{|c|c|c|c|c|c|c|c|}
\hline $\begin{array}{l}\text { Dependent } \\
\text { Variables }\end{array}$ & & $\begin{array}{c}\text { Unstandardized } \\
\text { Coefficients } \\
\text { B } \\
\end{array}$ & $\mathrm{t}$ & Sig. & $\mathrm{R}^{2}$ & $\mathrm{~F}$ & Sig. \\
\hline \multicolumn{8}{|c|}{ Period of Januari 2020 - April 2020} \\
\hline \multirow{9}{*}{$\begin{array}{l}\text { Stock Abnormal } \\
\text { Return }\end{array}$} & (Constant) & -0.490 & -1.607 & 0.108 & \multirow{9}{*}{0.214} & \multirow{9}{*}{21.358} & \multirow{9}{*}{0.000} \\
\hline & Vol & 0.604 & 10.190 & 0.000 & & & \\
\hline & MCap & -0.222 & -6.994 & 0.000 & & & \\
\hline & EPS & 0.000 & -1.792 & 0.073 & & & \\
\hline & BVS & 0.000085 & 2.119 & 0.034 & & & \\
\hline & PER & 0.000 & 0.769 & 0.442 & & & \\
\hline & PBV & 0.022 & 2.719 & 0.007 & & & \\
\hline & $\mathrm{N}$ & 2664 & & & & & \\
\hline & $\alpha$ & 0.05 & & & & & \\
\hline \multicolumn{8}{|c|}{ Period of Before The Announcement WHO Covid-19 Pandemic } \\
\hline \multirow{9}{*}{$\begin{array}{l}\text { Stock Abnormal } \\
\text { Return }\end{array}$} & (Constant) & 0.707 & 2.506 & 0.012 & \multirow{9}{*}{0.150} & \multirow{9}{*}{6.783} & \multirow{9}{*}{0.000} \\
\hline & Vol & 0.246 & 4.437 & 0.000 & & & \\
\hline & MCap & -0.159 & -5.643 & 0.000 & & & \\
\hline & EPS & 0.000 & -0.915 & 0.361 & & & \\
\hline & BVS & $4.918 \mathrm{E}-5$ & 1.266 & 0.206 & & & \\
\hline & PER & 0.000 & -0.613 & 0.540 & & & \\
\hline & PBV & 0.018 & 2.387 & 0.017 & & & \\
\hline & $\mathrm{N}$ & 1787 & & & & & \\
\hline & $\alpha$ & 0.05 & & & & & \\
\hline \multicolumn{8}{|c|}{ Period of After The Announcement WHO Covid-19 Pandemic) } \\
\hline \multirow{9}{*}{$\begin{array}{c}\text { Stock Abnormal } \\
\text { Return }\end{array}$} & (Constant) & -1.609 & -2.311 & 0.021 & \multirow{9}{*}{0.278} & \multirow{9}{*}{12.184} & \multirow{9}{*}{0.000} \\
\hline & Vol & 1.032 & 7.812 & 0.000 & & & \\
\hline & MCap & -0.283 & -3.524 & 0.000 & & & \\
\hline & EPS & .000 & -0.812 & 0.417 & & & \\
\hline & BVS & $6.873 \mathrm{E}-5$ & 0.840 & 0.401 & & & \\
\hline & PER & 0.003 & 2.540 & 0.011 & & & \\
\hline & PBV & 0.017 & 0.944 & 0.345 & & & \\
\hline & $\mathrm{N}$ & 877 & & & & & \\
\hline & $\alpha$ & 0.05 & & & & & \\
\hline
\end{tabular}


C. The Relationship between Stock-trading Volume, Market Capitalization, and Firms' Accounting Variables to Stocks' Abnormal Returns

Table III shows the regression results for the relationship between trading volume (Vol), market capitalization (MCap), earnings per share (EPS), book value per share (BVS), the price-to-earnings ratio (PER), price-to-book value (PBV) and stocks' abnormal returns (AR). Stocks' trading volumes $(\mathrm{Vol})$ positively affected their abnormal returns (AR) for the period January 1 to April 30, 2020 (b $=0.604 ; \mathrm{t}=10.190$, and sign. $=0.000<0.05)$, and both before the WHO announcement $(\mathrm{b}=0.246 ; \mathrm{t}=4.437$, and sign. $=0.000<0.05)$ and afterwards $(b=1.032 ; \mathrm{t}=7.812$, and sign. $=0.000<0.05)$. This result suggests that stocks' trading volumes positively affect these stocks' abnormal returns for all of the periods investigated.

Stock market capitalization (MCap) negatively affected stocks' abnormal returns for the period January 1 to April 30,2020 ( $b=-0.222 ; \mathrm{t}=-6.994$, and sign. $=0.000<0.05$ ) before the WHO announcement $(b=-0.159 ; \mathrm{t}=-5.643$, and sign. $=0.000<0.05)$ and afterward $(b=-0.283 ; \mathrm{t}=-3.524$, and sign. $=0.000<0.05)$. This result suggests that these stocks market capitalizations negatively affected their abnormal returns for all of the periods investigated.
Earnings per share (EPS) had no effect on stocks' abnormal returns from January 1 to April 30, 2020, both before and after the WHO announcement (sign. >0.05). However, the price-earnings ratio (PER) positively affected stocks' abnormal returns for the period after the announcement, with $\quad \mathrm{b}=0.004 ; \quad \mathrm{t}=2.540$; $\quad$ and sign. $=0.011<0.05$, but had no effect from January 1 to April 30,2020 . This result suggests profitability in terms of the price-to-earnings ratios (PER) positively affected stocks' abnormal returns during the period after the WHO announcement that the spread of COVID-19 is a pandemic.

The book value per share (BVS) positively affected stocks' abnormal returns from January 1 to April 30, 2020, with $b=0.000085 ; t=2.119$; and sign. $=0.034(<0.05)$, but had no effect on stocks' abnormal returns in the period immediately before and after the WHO. The price-to-book ratio (PBV) positively affected stocks' abnormal returns from January 1 to April 30, 2020, with $b=0.022 ; t=2.719$; and sign. $=0.007 \quad(<0.05)$, and for the period before the announcement, with $\mathrm{b}=0.018 ; \mathrm{t}=2.387$; and sign $=0.017$ $(<0.05)$. This result suggests that the book value per share (BVS) positively affected stocks' abnormal returns during the period January 1 to April 30, 2020. The price-to-book ratio (PBV) also had the same effect.

\begin{tabular}{|c|c|c|c|}
\hline & Hypothesis & Verification & Description \\
\hline H1 & $\begin{array}{l}\text { Stock returns are higher in the period after a financial } \\
\text { crisis than before a financial crisis* }\end{array}$ & - Supported & - \\
\hline $\mathrm{H} 2$ & Stocks' trading volumes positively affect stock returns & - Partly supported & $\begin{array}{l}\text { - Period January 1-April 30, } 2020 \\
\text { - Period after the WHO announcement }\end{array}$ \\
\hline $\mathrm{H} 3$ & $\begin{array}{l}\text { Stocks' market capitalizations negatively affect stock } \\
\text { returns }\end{array}$ & Supported & - All periods investigated \\
\hline $\mathrm{H} 4$ & Firms' profitability positively affects stock returns & - Partly supported & $\begin{array}{l}\text { - Period before the } \\
\text { announcement }\end{array}$ \\
\hline H5 & Firms' book value positively affects stock returns & - Partly supported & $\begin{array}{l}\text { - Period before the WHO } \\
\text { announcement }\end{array}$ \\
\hline H6 & $\begin{array}{l}\text { Stock trading volumes positively affect abnormal stock } \\
\text { returns }\end{array}$ & - Supported & - All periods investigated \\
\hline $\mathrm{H} 7$ & $\begin{array}{l}\text { Stock market capitalization negatively affects abnormal } \\
\text { stock returns }\end{array}$ & - Supported & - All periods investigated \\
\hline H8 & $\begin{array}{l}\text { Firms' profitability positively affects abnormal stock } \\
\text { returns }\end{array}$ & - Partly supported & $\begin{array}{l}\text { - PER for the period after the WHO } \\
\text { announcement } \\
\text { - EPS has no effects }\end{array}$ \\
\hline H9 & $\begin{array}{l}\text { Firms' book value positively affects abnormal stock } \\
\text { returns }\end{array}$ & - Partly supported & $\begin{array}{l}\text { - BVS for the period January 1-April } \\
30,2020 \\
\text { - PBV for the period January 1-April } \\
30,2020 \\
\text { - PBV for the period before the WHO } \\
\text { announcement }\end{array}$ \\
\hline
\end{tabular}

Notes: EPS is earnings per share; PER is price-earnings ratio; BVS is book value per share; PBV is price-to-book value per share.

* Even though the financial crisis related to the COVID-19 pandemic is not over, we can still extrapolate the findings to a post-financial-crisis period.

\section{Discussions}

This study accepts that the financial crisis that has been occurring since January 2020 due to COVID-19 pandemic and caused a trough in the world stock market indices since March 23, 2020. Since early April most of the developing world's stock market indices were down by more than $20 \%$ and those of emerging markets were down by more than $35 \%$ compared to the pre-pandemic period (Patel and Sarkar, 1998). To find our targeted aim for the Indonesia Stock Exchange, this study investigates differences in stocks' returns during the period before and after March 11, 2020, and especially when the WHO announced COVID-19 as an outbreak as a pandemic. Precisely, this study investigates how trading volume, market capitalization, firm profitability and book value affect stock returns on the Indonesia Stock Exchange due pre and post to COVID-19 pandemic. To investigate in detail how Indonesian investors reacted, data of 70 firms (e.g. $75 \%$ of the index's total market capitalization and firms) in the Indonesia Stock Exchange uses. The period considers between January 1 and April 30, 2020, and divides into two phases: (i) period before and (ii) period after WHO's announcement that the COVID-19 outbreak considered as a pandemic on March 11, 2020.

It is factual from the literature that when a financial crisis 
occurs, stocks' prices decrease so significantly that, after falling to their lowest level (trough), there is a reversal or rebound and, technically, a significant increase in stock prices may also occur occur (Öztek \& Öcal, 2017; Jiang et al., 2017; Gulzar et al., 2019; Zhang et al., 2020). Stock returns are higher during any periods after financial crises, and these increases can even be much higher than usual, resulting in abnormal returns in may cases (Choi \& Yoon, 2020; Endri et al., 2020; Wang et al., 2017; Jin \& An, 2016; Guo et al., 2011; Mishkin 1996). Some recent studies identified that during financial crises, investors trade more actively (selling and buying) and price volatilities mostly are higher than those of normal periods (Abreu \& Mendes, 2020; Mahenthiran et al., 2020). During unusual periods (e.g., crisis), investors trade more heavily and stock price volatility (trading volume) moves up or down more substantially (Tooze, 2018) ${ }^{1}$. This movement causes the returns to stocks with higher market capitalizations ${ }^{2}$ to fall below those of small-market-capitalization stocks.

With recent COVID-19 pandemic background, this study investigates how Indonesian investors reacted when Indonesia's stock market index declined dramatically from January 1 to April 30, 2020 in the Indonesia Stock Exchange. To have a robust insight, this study thus evaluates the influence of five variables such as stock's trading volumes, profitability, book values, stock returns and market capitalization, and there are nine hypotheses are examined in detail by using the data of 70 listed firms listed in the Indonesia Stock Exchange. This study on the whole tests the stock returns in the stock market index before and after the WHO's COVID-19-pandemic announcement. The overall findings are gathered are quite appealing to the finance literature and for stock-market participants during financial crises.

The study results support hypothesis H-1 and indicated that stocks' returns are higher in the periods after financial crises than before financial crises. The similar findings earlier addressed by Tooze (2018) and Bellofatto et al. (2018). The study results also support hypothesis H-2 that stocks' trading volumes positively affect stock returns, except for the period before the WHO's announcement. Several earlier similar studies indicate similar notions in light of any financial crisis (Rossi \& Gunardi, 2018; Chae \& Kang, 2019; Yang et al., 2020). However, outcomes from the study result do not support hypothesis $\mathrm{H}-3$, that stock market capitalization negatively affects stock returns. Several studies indicate similar ideas in earlier instances (Fornell et al., 2016; Mazur et al., 2020'Al-Awadhi et al., 2020). This study further investigates firms' profitability and book values on stock returns which are explored by hypotheses 4 and 5 respectively and all are duly supported. Additionally, firms' trading volumes, market capitalizations, profitability and book value are finally tested by the hypotheses $6,7,8$ and 9 , respectively and all are also

\footnotetext{
${ }^{1}$ The higher the price volatility, the higher the returns, so that the volume of stock transactions positively affect returns.

${ }^{2}$ The stock market capitalization is the sum of the number of shares outstanding multiplied by the current market price. A higher market capitalization means more shares are outstanding and owned by investors; this results in more bids or asks for these stocks. To increase stock prices, more investors need to make trades. However, the lower the market capitalization, the fewer investors willing to trade and push stock prices up.
}

supported duly. Similar findings uncover by several contemporary research works (Sugiarto, 2011; Leite et al., 2018; Granville, 2018; Zuhroh, 2019).

According to the study observation, overall it is noticed that earnings per share (EPS) positively affected stock returns for the period before the WHO's announcement that the spread of the COVID-19 was a pandemic. However, price-to-earnings ratios showed abnormal returns only during the period of after the announcement. Investors made their investment decisions during the first quarter, before the WHO's announcement; they considered firms' profitability and whether these firms paid dividends. However, for the period after the announcement, the price-to-earnings ratios (PER) lead to abnormal stock returns; this means that the higher a stock's price-to-earnings ratio, the higher its abnormal returns.

It is also observed that investors consider firms' book values when they buy stocks during the normal periods but not during the period of crises. Investors only consider stocks that are likely to increase in price due to a significant decline in previous days. It is evident from the past literature that when a financial crisis occurs, the opportunity to earn abnormal returns is greater than it is during the period before the crisis. Therefore, according to the findings, this study suggests that if investors want to earn abnormal returns, they should invest in stocks during a financial crisis and they should choose stocks that perform well in terms of firms' profitability and book value, and that have a lower value of market capitalization. These stocks should also be among those investors trade in the most.

\section{CONCLUSION}

This study investigates the reaction of Indonesian investors to the drop in stock prices on the Stock Exchange and finds the relationship between stock returns and motive of investors by the pandemic during the early months of the COVID-19 crisis, and especially before and after the World Health Organization (WHO) announced that COVID-19 is global spread constitutes a pandemic. To understand the reaction of Indonesian investors and impacts on the market this study explores five key variables such as trading volume, market capitalization, profitability, and book value for the period December 31, 2019 to April 30, 2020, and how pandemic influences stock returns by using regression analysis. This study recommends that when a financial crisis occurs, investors should begin buying stocks or increasing their stock purchases to achieve abnormal returns by choosing stocks that perform well in terms of firm profitability and book value. The impact of the COVID-19 decreased the value of market capitalization during the study periods, however, it is noticed that investors prefer to tradein to those firms whose market influence had solid longterm marks within several financial factors. The study outcomes will be useful for the investors in the Indonesia Stock Exchange in future and elsewhere with similar economy settings. 


\section{REFERENCES}

[1] Abreu, M., \& Mendes, V. (2020). Do individual investors trade differently in different financial markets?. The European Journal of Finance, 1-18.

[2] Aggarwal, R., Hiraki, T., \& Rao, R. P. (1992). Price/book value ratios and equity returns on the Tokyo Stock Exchange: Empirical evidence of an anomalous regularity. Financial Review, 27(4), pp. 589-605.

[3] Al-Awadhi, A. M., Al-Saifi, K., Al-Awadhi, A., \& Alhamadi, S. (2020). Death and contagious infectious diseases: Impact of the COVID-19 virus on stock market returns. Journal of behavioral and experimental finance, 100326

[4] Al-Awadhi, A. M., Al-Saifi, K., Al-Awadhi, A., \& Alhamadi, S. (2020). Death and contagious infectious diseases: Impact of the COVID-19 virus on stock market returns. Journal of Behavioral and Experimental Finance, 100326.

[5] Ali, M., Alam, N., \& Rizvi, S. A. R. (2020). Coronavirus (COVID19)-An epidemic or pandemic for financial markets. Journal of Behavioral and Experimental Finance, 100341

[6] AlNajjar, F. K., \& Riahi-Belkaoui, A. (1999). Multinationality, profitability and firm value. Managerial Finance. Vol. 25 No. 12, pp. $31-41$.

[7] Amihud, Y. (2002). Illiquidity and stock returns: cross-section and time-series effects. Journal of financial markets, 5(1), 31-56

[8] Ashraf, B. N. (2020). Economic impact of government interventions during the COVID-19 pandemic: International evidence from financial markets. Journal of Behavioral and Experimental Finance, 27, 100371.

[9] Baker, M., \& Wurgler, J. (2006). Investor sentiment and the cross-section of stock returns. The journal of Finance, 61(4), 16451680 .

[10] Baker, S. R., Bloom, N., Davis, S. J., Kost, K. J., Sammon, M. C., \& Viratyosin, T. (2020). The unprecedented stock market impact of COVID-19 (No. w26945). National Bureau of Economic Research.

[11] Baur, D. G., Dimpfl, T., \& Jung, R. C. (2012). Stock return autocorrelations revisited: A quantile regression approach. Journal of Empirical Finance, 19(2), 254-265.

[12] Bellofatto, A., D'Hondt, C., \& De Winne, R. (2018). Subjective financial literacy and retail investors' behavior. Journal of Banking \& Finance, 92, 168-181.

[13] Chae, J., \& Kang, M. (2019). Low-volume return premium in the Korean stock market. Pacific-Basin Finance Journal, 58, 101204

[14] Chen, S. S. (2012). Revisiting the empirical linkages between stock returns and trading volume. Journal of Banking \& Finance, 36(6) 1781-1788.

[15] Choi, K. H., \& Yoon, S. M. (2020). Investor Sentiment and Herding Behavior in the Korean Stock Market. International Journal of Financial Studies, 8(2), 34.

[16] Endri, E., Abidin, Z., Simanjuntak, T. P., \& Nurhayati, I. (2020). Indonesian Stock Market Volatility: GARCH Model. Montenegrin Journal of Economics, 16(2), 7-17.

[17] Fama, Eugene F. dan Kenneth R. French (2008), "Dissecting Anomalies", The Journal of Finance, Vol. LXIII, No. 4, pp.16531678.

[18] Fornell, C., Morgeson III, F. V., \& Hult, G. T. M. (2016). Stock returns on customer satisfaction do beat the market: gauging the effect of a marketing intangible. Journal of Marketing, 80(5), 92-107.

[19] French, K. R., Schwert, G. W., \& Stambaugh, R. F. (1987). Expected stock returns and volatility. Journal of financial Economics, 19(1), 3.

[20] Garcia, V. F., \& Liu, L. (1999). Macroeconomic determinants of stock market development. Journal of Applied Economics, 2(1), 2959.

[21] Girard, Eric. dan Rita Biswas (2007), "Trading Volume and Market Volatility: Developed versus Emerging Stock Markets", The Financial Review, 42, pp. 429-459

[22] Granville, J. E. (2018). Granville's New Key to Stock Market Profits. Pickle Partners Publishing.

[23] Guidolin, Massimo \& Tam, Yu Man, 2013. "A yield spread perspective on the great financial crisis: Break-point tes evidence," International Review of Financial Analysis, Elsevier, vol. 26(C), pages 18-39.

[24] Gulzar, S., Mujtaba Kayani, G., Xiaofen, H., Ayub, U., \& Rafique, A. (2019). Financial cointegration and spillover effect of global financial crisis: A study of emerging Asian financial markets. Economic research-Ekonomska istraživanja, 32(1), 187-218.

[25] Guo, F., Chen, C. R., \& Huang, Y. S. (2011). Markets contagion during financial crisis: A regime-switching approach. International Review of Economics \& Finance, 20(1), 95-109.
[26] Hao, S., Jin, Q., \& Zhang, G. (2011). Investment growth and the relation between equity value, earnings, and equity book value. The Accounting Review, 86(2), 605-635.

[27] Indrayono, Yohanes, 2011. "Disposition Effect Terhadap Hubungan Antara Nilai Fundamental dan Harga Saham Pada Periode Krisis Finansial", Jurnal Keuangan dan Perbankan, Vol.15, No.3 September 2011, hlm. 315-326

[28] Jiang, Y., Yu, M., \& Hashmi, S. M. (2017). The financial crisis and co-movement of global stock markets - A case of six major economies. Sustainability, 9(2), 260.

[29] Jin, X., \& An, X. (2016). Global financial crisis and emerging stock market contagion: A volatility impulse response function approach Research in International Business and Finance, 36, 179-195.

[30] Klingebiel, D., Claessens, S., \& Schmukler, S. (2002). Explaining the Migration of Stocks from Exchanges in Emerging Economies to International Centers. The World Bank.

[31] Lee, B. S., \& Rui, O. M. (2002). The dynamic relationship between stock returns and trading volume: Domestic and cross-country evidence. Journal of Banking \& Finance, 26(1), 51-78.

[32] Lei, Z., \& Shcherbakova, A. V. (2015). Revealing climate change opinions through investment behavior: Evidence from Fukushima. Journal of Environmental Economics and Management, 70, 92-108.

[33] Leite, A. L., Klotzle, M. C., Pinto, A. C. F., \& da Silva, A. F. (2018). Size, value, profitability, and investment: Evidence from emerging markets. Emerging Markets Review, 36, 45-59.

[34] Macagnan, C. B. (2009). Voluntary disclosure of intangible resources and stock profitability. Intangible Capital, Vol. 5, No. 1.pp.1-32.

[35] Mahenthiran, S., Gjerde, T., \& Silva-Palavecinos, B. (2020). Stock Market Contagion during the Global Financial Crises: Evidence from the Chilean Stock Market. International Journal of Financial Studies, $8(2), 26$.

[36] Majid, M. Shabri Abd. and Benazir (2015). An Indirect Impact of the Price to Book Value to the Stock Returns: An Empirical Evidence from the Property Companies in Indonesia. Jurnal Akuntansi dan Keuangan, Vol. 17, No. 2, November 2015, pp. 91-96.

[37] Mazur, M., Dang, M., \& Vega, M. (2020). COVID-19 and the march 2020 stock market crash. Evidence from S\&P1500. Finance Research Letters, 101690.

[38] Mazur, M., Dang, M., \& Vega, M. (2020). COVID-19 and the march 2020 stock market crash. Evidence from S\&P1500. Finance Research Letters, 101690.

[39] Meligkotsidou, L., Panopoulou, E., Vrontos, I. D., \& Vrontos, S. D. (2019). Out-of-sample equity premium prediction: A complete subset quantile regression approach. The European Journal of Finance, 1-26.

[40] Mishkin, F. S. (1996). Understanding financial crises: a developing country perspective (No. w5600). National Bureau of Economic Research.

[41] Naik, P. K., \& Padhi, P. (2015). On the linkage between stock market development and economic growth in emerging market economies: Dynamic panel evidence. Review of Accounting and Finance, 14(4), 363-381.

[42] Öztek, M. F., \& Öcal, N. (2017). Financial crises and the nature of correlation between commodity and stock markets. International Review of Economics \& Finance, 48, 56-68.

[43] Patel, Sandeep A. dan Asani Sarkar (1998), "Crises in Developed and Emerging Stock Markets", Financial Analysts Journal, Nov-Dec, pp.50-59

[44] Pathirawasam C (2011) The Relationship between Trading Volume and Stock Returns. J Competitiveness 3: 41-49.

[45] Phan, D. H. B., \& Narayan, P. K. (2020). Country responses and the reaction of the stock market to COVID-19-A preliminary exposition. Emerging Markets Finance and Trade, 56(10), 2138 2150.

[46] Poon, S. H., \& Granger, C. W. (2003). Forecasting volatility in financial markets: A review. Journal of economic literature, 41(2), 478-539.

[47] Ravichandran, K., \& Bose, S. (2012). Relationship between stock return and trading volume. Research Journal of Business Management, 6(1), 30-39.

[48] Rossi, M., \& Gunardi, A. (2018). Efficient market hypothesis and stock market anomalies: Empirical evidence in four European countries. Journal of Applied Business Research (JABR), 34(1), 183 192.

[49] Rui, Oliver. M, Gong-meng Chen, Michael Firth (2001). The Dynamic Relation Between Stock Returns, Trading Volume, and Volatility. Financial Review, 36(3, pp.153-73.

[50] Sabri, Nidal Rashid (2008), "The impact of trading volume on stock price volatility in the Arab economy", Journal of Derivatives \& Hedge Funds, Vol. 14, pp. 285-298 
[51] Sadka, G. (2007), "Understanding Stock Price Volatility: The Role of Earnings”, Journal of Accounting Research, 45 (1), pp. 199-228.

[52] Sadka, Gil. and Ronnie Sadka (2009). Predictability and the EarningsReturn Relation. Journal of Financial Economics, 94(1), pp. 87-106.

[53] Sugiarto, A. (2011). Analysis of Effect of Beta, Company Size, DER and PBV Ratio Stock Return. Journal of Accounting Dynamics, 3(1), $8-14$.

[54] Tooze, A. (2018). Crashed: How a decade of financial crises changed the world. Penguin.

[55] Ur Rehman, H., \& Gul, F. (2017). Stock Return Predictability Using Panel Regression: Empirical Evidence from Pakistani Equity Market. Journal of Managerial Sciences, 11(2).

[56] Wagner, A. F. (2020). What the stock market tells us about the postCOVID-19 world. Nature Human Behaviour, 4(5), 440-440.

[57] Wang, G. J., Xie, C., Lin, M., \& Stanley, H. E. (2017). Stock market contagion during the global financial crisis: A multiscale approach. Finance Research Letters, 22, 163-168.

[58] Yang, D., Ma, T., Wang, Y., \& Wang, G. (2020). Does Investor Attention Affect Stock Trading and Returns? Evidence from Publicly Listed Firms in China. Journal of Behavioral Finance, 1-14.

[59] Zhang, J. B., Gao, Y. C., \& Cai, S. M. (2020). The hierarchical structure of stock market in times of global financial crisis. Physica A: Statistical Mechanics and its Applications, 542, 123452.

[60] Zuhroh, I. (2019). The Effects of Liquidity, Firm Size, and Profitability on the Firm Value with Mediating Leverage. KnE Social Sciences, 203-230. 